Community: volume 7, nomor 1, April 2021

p-ISSN: 2477-5746 e-ISSN: 2502-0544

\title{
Asabiyah and Religious Solidarity \\ (A Socio-Historical Analysis of Asabiyah's Ibn Khaldun in relation to the Concept of Muslim Unity)
}

\author{
Khairulyadi $^{1}$, Bukhari $^{2}$, Masrizal $^{3}$, Akmal Saputra $^{4}$, Triyanto $^{5}$ \\ $1,2,3$ Prodi Sosiologi Universitas Syiah Kuala Banda Aceh \\ ${ }^{4,5}$ Prodi Sosiologi Universitas Teuku Umar Meulaboh \\ khairulyadi@gmail.com ${ }^{1}$, bukhari.yusuf@gmail.com ${ }^{2}$, masrizalfisip@unsyiah.co.id $^{3}$, \\ $\underline{\text { akmalsaputra@utu.ac.id }}^{4}$, triyanto@utu.ac.id $^{5}$
}

\begin{abstract}
Abstrak
Asabiyah merupakan kecenderungan solidaritas dalam kelompok, acap digunakan untuk menilai stabilitas dan kohesivitas kelompok sosial tertentu. Peran asabiyah sangat menentukan lahir dan runtuhnya sebuah bangsa, negara dan peradaban. Tulisan ini mengunakan pendekatan sosio-historis, bertujuan untuk menganalisa konsep asabiyah Ibnu Khaldun dan bagaimana konsep ini terkait dengan solidaritas berdasarkan agama. Solidaritas agama, misalnya, telah mendorong usaha menyatukan negara Islam seperti gerakan Pan-Islamisme, Persatuan Arab dan Persatuan Muslim. Data untuk tulisan ini dikumpulan melalui pendekatan analisa dokumen (document analysis). Tulisan ini mendapati bahwa antara asabiyah dan solidaritas agama memiliki hubungan yang mutuallyinclusive. Bahwa, asabiyah memiliki peran penting dalam kemunculan awal sebuah negara dan peradaban. Sedangkan solidaritas agama diperlukan sebagai identitas dan kesadaran yang menyatukan perbedaan identitas budaya dan etnis (asabiyah) dalam sebuah negara dan aliansi. Pada tahapan awal lahirnya sebuah negara asabiyah sangat diperlukan sebagai pemantik semangat juang dan keberanian. Sementara solidaritas agama bisa menekan etnosentrisme dan menghilangkan persaingan, kecurigaan dan kecemburan di antara entitas etnis yang berbeda. Ringkasnya, identitas budaya dan etnis (asabiyah) dan solidaritas agama saling membutuhkan dan menguatkan terutama untuk mencapai pembangunan dan kemajuan. Jika ikatan asabiyah menguat tanpa ikatan solidaritas agama akan memicu kemunduran dan keruntuhan bagi sebuah negara dan peradaban.
\end{abstract}

\section{Kata kunci: Asabiyah, Solidaritas Agama, Persatuan dan Solidaritas Muslim}

\section{Introduction}

Ibn Khaldun is one of the most outstanding thinkers in the Islamic world and beyond. Many of his ideas are still relevant to be implemented in the present time. The awareness of how the past has molded the present especially in the Muslim world is affected by the study of his ideas (al-Azmah, 1990). A number of studies have been undertaked to analyze some of his the concepts from many different perspectives. For example, the concept of asabiyah has been studied in term of the rise and the fall of a state (Baali, 1998), and also in the light of economical perspective (Firzly, 1990, 
Muheramtohadi, 2018), Islamic studies (AbHalim, 2014), and antropological studies (Gierer, 2001).

In socialogical domain, some studies have also addressed Khaldun's thoughts particularly on how asabiyah relates to, and helps build methodological framework for, structural analysis of social integration (SÜMER, 2012, Alagha, 2017, Shahidipak, 2020). However, there are no adequate studies have been undertaken to see the influences of asabiyah in fostering religious-based solidarity. Therefore, this paper tries to analyse the concept of asabiyah Ibn Khaldun and how it may affect the senses of brother hood and solidarity that is formed by shared religious identity among larger and wider muslim society.

The term "Asabiyah has been defined as tribal consciousness, blood relationship "esprit de corps", partisanship, feeling of unity the solidarity of a group, sense of solidarity to own group (Baali, 1998). This leads to the understanding that asabiyah is only existed in a structure of small scale community, and as such, it is seen a hindrance to larger solidarity formed by religious senses and identity across nations as well as to the idea of progress and development.

The basic concept of unity is always based on Islam as universal religion. Islam does place muslim, whichever place they might belong to, in special relationship toward each others. This sense of belonging to community of common brotherhood has provided the basis for solidarity and unity at least at the emotional level in spite of the difficulties muslim and all muslim country politically to be bound in what so called khilafah (in Tibi, 1997).

Furtheremore, muslim unity and solidarity, as a religion and ethical bond, is the highest spiritual end. Recognizing its importance, the concept of Muslim unity and solidarty has brought about, to mention but a few, the idea of Arab Unity and panIslamism (Ali; 1976, Mia, 1980, Khalaji, 2009). Unfortunately, it did not last long. Ali argues that among the most important factors which cause the decline of Pan-Islamism is territorial nationalism. He explains that the rise secular nationalism, based on territory and sovereignty of each state was the biggest setback to muslim solidarity and unity (Ali; 1976, Khalaji, 2009).

In short, the unity of the muslim community has suffered under the onslaughts of parochial tendencies of regional sometime reinforced by ethnic, lingual and other affinities. Ibn Khaldun called all these barriers as asabiyah. Asabiyah of Ibn Khaldun, seems to have contradictory standpoint with religious solidarity. As a result, this paper is an attempt to find out the relationship between the two concepts. Using social historical approach, the paper links the analysis of the dimensions of social genesis and historical evidences (Hall, 1992, Hall, 2007, Prior, 2012, Keizer, 2015) through documents analysis (Bowen, 2009) to the actual situation

Three important questions the paper tries to answer are as follows: 
Community: volume 7, nomor 1, April 2021

p-ISSN: 2477-5746 e-ISSN: 2502-0544

1. What is the historical background that gives rise to Khaldun asabiyah concept?

2. To what extent does asabiyah and religious solidarity affect the rise and the fall of Arab unity and Muslim unity?

3. What is the relationship between these two concepts, ccontradictory or complementary?

\section{Literature Review}

\section{Ibn Khaldun's asabiyah concepts}

Ibn Khaldun is a philosopher and also known as a sociologist. His monumental work Muqaddimah (prologemena) has been well known worlwide. Arnord Toynbee called this as "the greatest work of its kind" (in Tibi, 1997, p. 138). Rosenthal sees muqaddimah as "the most remarkable work of history and social philosophy" and as 'one of mankind's important triumphs (In Khaldun, 1980, P. lxxxvii)

In Muqaddimah, Khaldun attempts to present an analytical framework explaining social factors that closely knit and bind small-scall human groups (such as tribes and community), more complex societies (such as states, dynasty), and also how the political establishment of caliphate affected by asabiyah and religion. Asabiyah is a dominant concept in his writing. He extensively discussed the role of asabiyah in a small-scale society which he calls as bedoin society and how it plays important role in the rise and the fall of civilization.

There has been debates on the translation of term asabiyah (Baali (1998, Firzly, 1990). Slane, renders asabiyah as the sprite de corps ( in Baali, 1998). Rosenthal, translates it as the feeling solidarity (in Khaldun, 1980, p. Ixxxvii). Simon (1978) considered solidarity as the most appropriate one for it covers instinctive, emotional and conscious aspect of a particular group. There are also some social scientists that render asabiyah as concepts of nationality even though rejected by many (Tibi, 1997).

Unfortunately, not all Khaldun's concepts have clearly been explained. Take example how the terms such as 'umran and also 'asabiyah should adequately be translated into other languages. The available translations to these two terms still remain debatable (Firzly, 1990). Asabiyah concepts also needs further explanation particularly regarding the comformity with Islamic norms (Ab Halim, 2014) and its contributrion to the rise of Pan -Arabism, nationalism or such another condition (Tibi, 1997).

In short, the term asabiyah can be best related to a primordial sentiment in a small group of peoples, which triggers solidarity and unity. Asabiyah plays certain roles in any cooperative and combative actions, as well as a natural feeling of compassion 
and natural support to defense and support of one's kin and blood relatives (Firzly, 1990). Baali, furthermore, explains that 'asabiyah is social sentiment that is used to determine cohesion and stability of social groups. Analogously, it is "just like the tendons ensure the cohesion of flesh to the bones" (Baali, 1998, p. 44). In a more elaborated interpretation, it too includes the extent it plays in unifying a rather complex stucture such as caliphate, or nationality.

To Khaldun, each group evolves from a simple small-scale society to the emergence of state. Asabiyah is particularly influential in former than in the latter. If asabiyah depletes, the group disintegrates, and its controling power is taken by group whose asabiyah is fitter and stronger. He also explains that the civilization would finally, by nature, downfalling, and the creation of new born civilization is always started by how asabiyah is circulated among a particular social groupsl.

Khaldun explains the core role of asabiyah in religion and political movements, like in the case of "prophecy or mulk (kingship) which do not ordinarily win the allegiance of the people without resort to fighting. And fighting cannot be achieved its goals without asabiyah" (In Firzly, 1990, p. 271) It may explain why Khaldun specifically devotes two sections in his book under the heading"religion causes cannot succeed without asabiyah " and "mulk or dynasties are attained through asabiyah and tribe" (Khaldun ,1980, p 322).

Furthermore, asabiyah, to Khaldun, in the first cycle, it emerges in nomadic society where the form of solidarity is dependent on common shared values and identity such as blood relationship and ancestry. This leads them to act and to behave in the same way that gives rise to group consciouness. In the next cycle asabiyah would be much depends on affiliation and protection within the group. Strong asabiyah would also make possible more extensive process of socialization which in itself will create a common feeling of communality and identity. This usually appears in a more complex structure such as in urban societies as a result of the social interaction. However, the escalation of scrutiny, discontent and jealousy would distrupt the longevity of asabiyah within social grouping (Khaldun, 1980).

In regard to the religion factor, Khaldun understands that religion could not replace Asabiyah, "religion bond cannot be the primordial form of social commitment" (Khaldun, 1980, p. 322). Eventhough, asabiyah in its further development has always continuing interaction with religion, Khaldun believes that religion makes asabiyah stronger and, likewise, "religious without asabiyah would be meaningless" (Khaldun, 1980, p 322).

\section{Religious and Muslim Solidarity and Unity}

The idea of unity and brotherhood is the affirmations of the oneness of God (tauhid). Oneness of God becomes a starting point of the concepts of unity and 
Community: volume 7, nomor 1, April 2021

p-ISSN: 2477-5746 e-ISSN: 2502-0544

brotherhood (al-Faruqi: 1982). It is enshrined in religious text such as in the Qur'an and the Hadith. Islam considers all believers to be brothers. God says" the believers are but a single brotherhood (AlQuran, 49;10). Islam also makes it a duty for them to establish a close relationship with one another and to support one another in doing what is right. There are several injections of the prophet which make it clearer that all muslims in spite of the social, cultural, and geographical differences are equal members of the universal community which should cooperate and be united as organs of a body; integrated components of one structure.

Likewise, the muslim unity and solidarity is always an integral part of the Muslim faith. The Quran says :

"lets there be one community among you, inviting men to good, bidding to honour, rejecting what is disapproved; such those who prosper. And be not as those who divided and fell into disagreement after a clear signs had come; for them there is a mighty punishment (Quran, 3;100)

In Hadith, there are also replete with reference to the eternal oneness of the Muslim community.

The rise of nationalism, however, dealt a severe blow to the strength and popularity of Muslim unity. The concepts of unity in brotherhood become only a decorative beautification of the faith. In spite of this setback, an average believer in practically every Muslim society continues to believe that the followers of the faith, irrespective of race and nationality have a religious duty to close their ranks in defense of common interest. This sentiment is based on the facts that territorial nationalism and all other manifestations of parochialism which stem out of race, language, tribe, are foreign to Islamic teaching.

Hence, muslim unity and solidarity is undestood as the feeling of togetherness which is bonded and knitted by religion, namely, Islam. This is because all Muslim have the same attitudes towards their religion whch is called five pillars of Islam (arkanul islam) namely facing the same Kiblah, bearing witness to the same God and the same Messenger, praying five times daily, fasting during the month of Ramadan, paying Zakat, and participating in Hajj (Hussain, 2012).

Raziq (1925, p. 8) states that:

"Islam is a noble advocacy, sent by God for the benefit of all this universe, east and west, its Arab and non Arab, men and women, poor and rich, learned and illiterate. It is a religion unit by which God wanted to gather mankind together, and to include all countries of the whole world. Islam has never been an Arab advocacy, an Arab unity, nor an Arab religion. Islam does not recognize a preference for one nation, one language, one country, one epoch, or generation over another except by piety" 


\section{Method}

The paper is a qualitative research, using document analysis approach (hodder, 2000, Creswell, 2012, Bowen, 2009, Prior, 2012). It refers to the proses of data collection through extensive search and exploration on related literatures, textbooks, bibliograhies, and journals articles. Some data are accessesed through librabry catalogs (printed documents), the others are retrieved from internet access and virtual resources (electronic and digital materials)

The paper collects primary sources from books that relates to, and relevant with, the the concepts of asabiyah and the formation of several social and political groups across nations that are formed based on religious solidarity. Secondary data are those that indirectly relates to the subject of the study. The data are analysed using docoment analysis procedures (Bowen, 2009, Hodder, 2000).

\section{Result and Discussion}

\section{Historical background of the concept of Asabiyah}

Although differences within the muslim emerged after the years of Prophet Muhammad passed way, the principle of unity of ummah embracing all muslim natonalities have been remained intact. Continually, after the period of Khulafaur rasyidin (first righteous caliphs) during the Umayyad in power, caliphate was indeed the sovereign on all lands which Muslim has conquered. The first infringements of unity of Muslim caliphate came in 756, when a Umayyad prince who fled from in the ruins of his family in the east, because ruler of Muslim Spain in defiance of the Abbasids (Antonious, 1939).

Soon after, the process of political fragmentations continued rapidly. After Spain and Tunisia falls into to independent dynasties, others appeared in eastern Iran and finally Egypt, Syria, Arabia and even part of Iraq were by the middle of tenth century lost the empirical government (Antonious, 1939)

It was in this condition of political fragmentation and the rise of nasionalism, Khaldun was born and raised. Khaldun has written his Magnus Opus to records and analyse all the events started from pre-Islamic until his life time ( al-Jabri, 1992). As such, asabiyah is historical evidence which is reported by Khaldun through his Muqaddimah. His aim was to describe and analyze human society based on careful observation, theoretical, cumulative and objective (Baali, \& Wardi, 1981).

Furthermore, describing the life of Arabs people and their condition is deemed significant in order to know the factors that have influenced Khaldun's thought on asabiyah. Based on what Khaldun has portrayed on life of Arabs in his muqaddimah, it might save to conclude that Arab people is the peoples who were divided into a lot of tribes and groups, rude and ambitious. He elucidates that as follows: 
Community: volume 7, nomor 1, April 2021

p-ISSN: 2477-5746 e-ISSN: 2502-0544

"The Arabs are incapable of founding an empire, except on religious basis such as the revolution of a prophet or a saint. Because their fierce characters, pride and jealousy of one another, especially in political matters, make them the most difficult people to lead"

( In Ali, 1976, p.18)

He also writes that:

"They had a nomad and isolated life, undefended by wall. They look for protection to themselves alone, always armed and watchful. They are ever on the lookout for any sign of dangers, being full of confidence in their own courage and power, for courage has become one of their deepest qualities and audacity is a second nature to them" (in Ali, 1976, p. 19)

It also important to refer to the history how Islam has eradicated the asabiyah form the life of Arabs. Baali and Wajdi (1981) argue that, since the time when Islam has been revealed, the prophet erased the narrow tribal spirit of the nomads and installed in its place the religion spirit. The prohet vehemently attacked the nomadic pride and preached that courage for faith was the only criterion of honor.

At first of course it was difficult, however, for the nomads to abandon the tribal spirit to which they had been accustomed since the beginning of their known history. Some of the Arabs, at that time, declared that " a false prophet from our tribe is better than a true one from the tribe of Quraisyh" (Baali \& Wardi, 198, p. 98).

Consequently, after the prophet passed away, this tribal feeling renounced. As Levy (1931, p.78) puts it," it is obvious that so intangible an element in social organization as a feeling of pride in ancestry was not to be destroyed by edict at one stroke". This is an evidence that shows that the tribal spirit, is one of the main factors underlying the nomadic feeling and solidarity still exist until the time of Khulafa ur Rasyidin, Umayyad and Abbasid up until the Islamic kingdom falling and spread away due to the political fragmentations.

This was the Arabs condition that was faced by Khaldun in his life time. One of the darkest periods in the history of Islam (Baali \& Wardi, 1981). What actually has been described by Khaldun was but a character of Arab people as he observed them. Some rejected this argument and argued that "Khaldun was a Berber who hated the Arabs merely because of his nationalistic sentiment against the conquerors of his home country" (Enan, 1969, p. 61). However, Toynbee explains that Khaldun's criticism of the arabs was on the basis of his objective observation and experience. He refers to the fact that Khaldun meant therefore "the Arabs of the South where the Badawi were settled". Khaldun did not mean to the whole Arabs (Toynbee, 1962, P. 324) 


\section{Asabiyah and the emergence of Arab unity and Muslim unity}

The Arab unity is conceived to be significant in order to know the Muslim unity. They have interwoven interaction. Al-Husri (in William, 1971) holds that Arab unity and islamic unity are not antithetical to each other. They are two separate facets of the same reality. To him, the idea of Islamic unity is broader and more inclusive than the concept of Arab unity.

Arab unity refers to the establisment of political union among Arab countries, the inhabitants of which speak Arabic. While the muslim unity is that the creation of political union of Muslim countries, the inhabitants of which profess the Muslim religion, regardless of their languages and races (Sharabi, 1963).

Another instance is the concept of Muslim unity. It has somehow given rise to the idea of pan-Islamism. Pan-islamism is a term that refers to the efforts which have been done by Islamic revivalist such Sultan Abd Hamid II, Jamal al- Din al-Afghany and Muhammad Abduh. It was aimed at uniting the Muslim world communities to unite together under one leadership (Ali, 1976, Mia, 1980, Maududi, 1982). Unfortunately, it did not last for long, because the rise of territorial nationalism, which is seen as "the biggest setback to Muslim solidarity and unity" (Ali, 1976, p. 200)

As have been explained before that Islam is a religion which aims at uniting all its followers to one unity regardless of their races and nationalities. There has been well-known through historical writings that the life of Arabs was determined by the tribe fighting power until the born of the Prophet Muhammad. The period before the coming of Islam is generally called by the Arabs as a'asr al-jahiliyah or the period of ignorance. Gogoi and Ghazy (1994) described such conditions by saying that Islam in general and Muhammad in particular have contributed a lot in establisment of the Arabs nations.

Historical facts, he continues, confirms the view the Islam and Muhammad were the first successful Arab leader to unify all people of the Arab peninsula under one authority (Gogoi and Ghazy, 1994). From the teachings of him, it is very obvious that the concept of solidarity is proposed, that all people are equal. The al-Quran states," Mankind was one single nation" (al Quran 2: 190)

When Islam has existed, the people of Arab peninsula were ready for a new social structure and social values and were ripe for a change within them. Islam gave them a new political doctrine of a united nation with a single faith and outlook (Hunter, 1998). Both were not only practicable but desirable. In al-Raihani's words: "Islam as civilization, as a mode of life and as an aspiration of unity, remained the background of the Arab national movement"(In Gogoi \& Abd-Ghafur, 1994, p. 45)

Nevertheless, it is beyond dissension that Muhammad did not profess Islam as a religion for Arabs only. Rather, it is a new faith for all people eventhough the Arabs are the first receivers. This connection between Islam and Arabism is reflected in 
Community: volume 7, nomor 1, April 2021

p-ISSN: 2477-5746 e-ISSN: 2502-0544

writing of many scholars. Faris, for example, writes; the birthday of the prophet is the birthday of the Arabism (In Gogoi \& Abd-Ghafur, 1994, p. 45)

This may not sound convincing but it is true that Muhammad made Islam a national cause of the Arabs because Islam was born in Arabia and develops the force that built up their strength and united under Islamic cause. They further broke out of the borders of Arab to carry the new mission beyond the boundaries of their land to the other world civilizations.

This is why the unity concepts, be muslim unity or Arab unity have been brought about which is very much based on the Islamic teaching. Unity itself is among the cardinal principles of the faith. Islam teaches that solidarity and the feeling of brotherhood among the members are emphasized and the followers should act toward each others like brothers (al-Qur'an, $39: 10$ ). In one of his sayings, the prophet declared that" mankind is the family of Allah, and so, the most beloved man in sight of Allah is that who is most helpful to his family" ( In al-Magribi, 1347, p. 128).

The problem would eventually arise is that the nomadic feeling among Arab nomadic society was, still is, "highly integrated within the tribal unit. Brotherhood, cooperation and loyalty was, and still is, held high among the members of the tribe, rich or poor, powerful or powerless" (Hitti, 1946, p. 26).

The Arab is, as Hitti (1946, P. 26 ) points out" a born democrat" but when they meet men from other tribes they become "ethnocentric". They look upon their tribe as the best and the most honorable one in the world. What Hitti has pointed out here may explain why disunity among Arab reemerge after the prohet passed away. Or at least it can prove Khaldun assumption that without religion propaganda, asabiyah will be the main factor in building a dynasty. When it appears, division would also appear and manifest itself in the face of nationalisme (In Ali, Shaukat. (1976). In spite of the successfulness of prophet in building the unity, however, it is always distrupted by the feeling of ethnocentrism or nationalism.

\section{Asabiyah and Religious solidarity and unity: Complimentary or Contradictory?}

The concept of Muslim community is very much based on religious bond than another. According to Khaldun, "mankind consists of various communities, whose existence is vested in the will of God. The individual can only exist in the community. Each community is like "a living organism, with own limbs, which are directed by a single soul" (Khaldun, 1980, p 322). He explain further " that every community is like a man, who is different from all other man in the stage of his life, his concerns, his fortunes and his misfortunes" (Khaldun, 1980, p. 416).

There are the two kinds of social allegiance which held unity together, namely, the natioal and the religious bond. Islam gives greater important to religious bond. Islam as a shared identity is more integrative and culturally laden than the national one. In Islamic civilisation, since its inception to the present day, shows that 
Muslim "acknowledged the bond of religion over and above any racial bond or national group solidarity" (Tibi, 1997). This is why "the Turks and Persians have no objection to the rule of the Arabs, as long as the ruler follows the Shariah" (Tibi, 1997, p.165) Even though, the conflict which involves these triangles power become "an indicator of the emergence of the national feeling" among them (Gogoi \& Abd-Ghafur, 1994, p. 59)

The concept of muslim unity is a fundamental bond in unifying muslim society. The racial or national bond is meaningless as far as the universalism of Islam is concerned. Consequently, there are no asabiyah (racial solidarity), national interests or other things which are beyond religion importance.

Therefore, Khaldun himself was aware that muslim unity is something important. That was why according to him religion is actually playing a significant role in building the structure of Muslim community. Khaldun says that though religion cannot replace asabiyah (Khaldun, 1980, p. 322), religious association and identity would be of imposing and strengthening factors for social solidarity and unity to be succesful particularly in a multicultural society. Asabiyah finds its peak and strongest expression when it is in a synthesis with religion. Hence, religious is but an ideology which colourises and strengthens asabiyah to its positive purposes.

Thus, asabiyah is actually human attributes by nature. It could never be united unless within which religion has a role to play. Khaldun then quotes AlQuran," if you had expended all the treasures on earth, you would have achieved no unity among them" (Khaldun, 1980. p 319).

To Khaldun, in additional to that of the group feeling, religion propaganda gives a uniting power to a dynasty particulaly at its inception. It could unify groups with differences in etnical and cultural background. This happens, according to Khaldun, because religion bond could erase mutual jealousy and envy among people and groups who have different asabiyah (Khaldun, 1980, p. 320). Likewise, in caliphate and in a state, religion is important factor strengthening asabiyah. Khaldun quotes a hadith: God sent no prophet who did not enjoy the protection of his people (Khaldun, 1980, p. 322)

Khaldun qoutes Quranic verses and hadith to comfirm that asabiyah is discouraged in Islamic teaching. God says; most noble among you in god's eyes is he who fears God most (al-Qur'an, 49: 10, Khaldun, 1980, p. 415). Muhammad says: God removed from you the arrogance of the pre-Islamic times and its pride in ancestors (Khaldun, 1980, p. 415), Khaldun explains that "the prophet recommended friendship among all Muslim and warned against discord and dissension" (Khaldun, 1980. p. 415)

It is evident, as previously mentioned, that Islam rejects asabiyah because it was a characteristic of the pre-Islamic bedouin tribes. Because of asabiyah, like the bedouin way of life, could not be easily eradicated, it was modified in favour of Islam since there are two concepts of asabiyah, one being bad asabiyah, governed by 
Community: volume 7, nomor 1, April 2021

p-ISSN: 2477-5746 e-ISSN: 2502-0544

primordialism and fanaticism toward their own group (exclusivism) and the other being the good asabiyah which is associated with bravery and patriotism which bond by religious solidarity.

Khaldun elucidated further that the asabiyah that directed towards futility and vanity (as in pre-Islamic times) is worthless, but when it is directed toward the truth and the fulfillment of divine commands, it is worth striving for (Khaldun, 1980, p. 416). He quotes a hadith: "Neither your blood relatives nor your children will be of use to you on the Day of resurrection" (Khaldun, 1980, p. 416). This naration is directed against asabiyah that is used for unproductive and useless purposes just like in preIslamic period. It is also intended against asabiyah that makes a person proud and superior. On the other hand, asabiyah that is working for the fulfillment of the divine commands is something desirable. "If it were gone, religious laws would no longer be, because it materializes only through asabiyah" (Khaldun, 1980, p. 416).

Threfore, the relation between asabiyah and religion as the means to unite people is obvious. Khaldun unmistakably considered religion dependent on asabiyah, that is, asabiyah as understood at the pre-Islamic times, have received a new colouring from Islam as a result of its universal intention. Asabiyah, as a cultural trait, is purposedly to serve a greater purpose namely unity and solidarity within societies consisting different cultural and etnical backround.

In a nutshell, according to Khaldun, asabiyah only takes its primodial role when the groups are still in its inception. Yet when the dynasty becomes broaden in large and increase in number of the population, besides asabiyah bond, religion too has significant role in unifying and knitting peoples and groups within a dynasty; that religious propaganda cannot materialize without group feeling. As such, Asabiyah and religious solidarity is therefore essential to muslim community. Its coexistence enables the community to create a sustainabel unity and solidarity.

\section{Conclusion}

Asabiyah is historical evidence which is reported by Khaldun through his Muqaddimah. It is based on careful observation on the situation of his life. It is to describe and analyze human society. Asabiyah is the feeling of solidarity that, more often than not, is used to measure the unity, solidarity and stability of any given social grouping.

To Khaldun, the relationship between asabiyah and Muslim unity and solidarity is mutually inclusive as far as far as human characters in nature such as the tribe feeling is a concern. However, such a nature can be reduced when it involves itself with religion. Not only is asabiyah a radical concept in building a dynasty but religion is also a unifying role strengthening shared sense of consciousness, identity and structural fucntioning within a state or a dynsaty. Khaldun believes that asabiyah is the esensial element that gives rise to religious solidarity such as the creation of Arabs 
unity, pan-Islamism and muslim unity. The unevitability of teritorial nasionalism (asabiyah) has made these religious-based alliances not lasting long. As such, it is save to assume that asabiyah could be a determinant element to the rise and the fall of an alliance, state and civilisation.

On one hand, asabiyah is needed in favoring the establishment a state or a new movement in that in implies bravery, courage and patriotism. On the other hand, religion censures group etnicentrism and fanatism and does away envy and jealousy. At this point, asabiyah and religious solidarity among muslim community and society can be best met. Cultural identity (asabiyah) would in fact only strengthen the shared religious bond and leads to progress and development. In contrast, asabiyah without religious bond would only lead to regression and disunity

\section{Bibliographies}

Ab-Halim, A., 2014. Ibn Khaldun's Theory of Asabiyyah and the Concept of Muslim Ummah. Journal of Al-Tamaddun, 9(1). 10.22452/JAT.vol9no1.1

al-Azmah. A., 1990. Ibn Khaldun. New York: Routledge.

al-Faruqi. I. R, 1982. Al-Tauhid, its Implication for Thought and Life. Herndon, Virginia: International Institute of Islamic Thought (IIIT).

Ali. S, 1976. Pan-Movements in the Third World, Pan-arabism. Pan-Africanism, PanIslamism. Lahore, Pakistan : Publishers United Ltd.

al-Magribi., 1928. al-ahkam wa al-Wajibah. Cairo : Salafiyah Press.

Antonious. G, 1939. The Arab Awakening; the Story of the Arab National Movement. . Philadelphia: J. B. Lippincott Company.

ar-Raziq. A, 1925. A Research in the Caliphate Government in Islam. Cairo : Matbaat Misr.

Baali. F, 1998. Society, State and Urbanism Ibn Khaldun's Sociolological Thought. New York: State University of New York.

Baali. F and Wardi. A, 1981. Ibn Khaldun and Islamic Thought-Styles. A Social Perspective. . Massachusetts: G. K. Hall And Co. Boston.

Bowen, G.A., 2009. Document Analysis as a Qualitative Research Method. Qualitative Research Journal, 9(2). 10.3316/QRJ0902027

Enan. M. U., 1969. Ibn Khaldun; His Life and Work. Lahore : Ashraf Press. 
Community: volume 7, nomor 1, April 2021

p-ISSN: 2477-5746 e-ISSN: 2502-0544

Firzly. G. S., 1990. Ibn Khaldun; A Socio Economic Study. Michigan: U. M. I. Dissertation Information Press.

Gierer, A., 2001. Ibn Khaldun on Solidarity (“Asabiyah”) - Modern Science on Cooperativeness and Empathy: a Comparison. Philosophia Naturalis. , p. 91 104, 38(1).

Gogoi. A \& Abdul-Ghafur. G. I, 1994. Arab Notionalism, Birth, Evolution and Present Dilemma. . New Delhi: S. Kumar Lancers Books.

Hall, J., 2007. Historicity and Sociohistorical Research. In: The SAGE handbook of social science methodology. London: SAGE Publications Ltd, .pp.82-101. $10.4135 / 9781848607958$

Hitti. P. K., 1946. History of the Arabs. 3rd ed. London : Macmillan.

Hodder, I., 2000. The Interpretation of Documents and Material Culture. In: \& L.Y.S. N. K. Denzin, ed. Handbook of Qualitative Research, 2ed ed. Thousand Oaks, CA: Sage. pp.703-715.

Hunter. T. S., 1998. The politics of Islamic Revivalism; Deversity and Unity. Bloominton: Indiana University Press.

Hussain, M., 2012. The Five Pillars of Islam: Laying the Foundations of Divine Love and Service to Humanity. Markfield, United Kingdom: Kube Publishing Ltd.

Ibrahim, K.M., 1990. An Analitical Study of Asabiyah: Ibn Khaldun's theory of Social Conflict. Michigan: U. M. I Dissertation Services.

Keizer, P., 2015. "The Historical Approach in Sociology". In: Multidisciplinary Economics. Oxford: Oxford University Press. pp.381-395.

Khalaji, M., 2009. The Dilemmas of Pan-Islamic unity. Current Trends in Islamist Ideology, 9, pp.64-79.

Khaldun, I. (translated by F.R.,) 1980. The Muqaddimah, An Introduction to History. New Jersey: Princenton University Press.

Levy. R, 1931. An introduction to the Sociology of Islam. London: William and Norgate Publications.

Maududy. A., 1982. Unity of The Muslim World. . 5th ed. Lahore : Islamic Publications.

Mia. A. J, 1980. Concepts of Unity. Dhaka, Bangladesh: Islamic Foundation. 
Muheramtohadi, S., 2018. A Comparative Study: The Economic Thoughts of Ibn Khaldun and Karl Marx. International Journal of Islamic Business and Economics (IJIBEC).

Prior, L., 2012. The Role of Documents in Social Research. In: S. Delamont, ed. Handbook of qualitative research in education. Cheltenham, UK: Edward Elgar. B.pp.426. -438 .

Shahidipak, M., 2020. Ibn Khaldun as a Paradigm for the Past and Future of Sociology and Humanity. Sociology International Journal, 4(5). 10.15406/sij.2020.04.00240

Sharabi, H.B., 1963. Haim, S. G (Ed.). Arab Nationalism: An Anthology. Pp. 255. Berkeley and Los Angeles: University of California Press, 1962.

Sümer. B, 2012. Ibn Khaldun's Asabiyya For Social Cohesion. Electronic Journal of Social Sciences. 11(41), pp. 253-257. 10.17755/esosder.95605

Toynbee. A.J., 1962. A study of History. New York: Oxford University Press. 